\title{
Effects of Capital Structure and Board Structure on Corporate Performance of Selected Firms in Nigeria
}

\author{
Henry Waleru Akani ${ }^{1}$ \\ Kenn-Ndubuisi Juliet Ifechi ${ }^{1}$
}

\begin{abstract}
${ }^{1}$ Department of Banking and Finance, Rivers State University, Nkpolu - Port Harcourt, Rivers State, Nigeria Correspondence: Henry Waleru Akani, Department of Banking and Finance, Rivers State University, Nkpolu Port Harcourt, Rivers State, Nigeria, Email: henryakani@yahoo.com
\end{abstract}

Received: October 14, 2017

Accepted: October 28, 2017

Online Published: November 01, 2017

\begin{abstract}
This paper seeks to examine the effect of capital structure and board structure on firm performance in Nigeria using secondary data consisting of forty listed companies on the Nigerian Stock Exchange (NSE) within the period of 2008 to 2016. Data were merged and pooled for analysis, the unit root test; co -integration, granger causality test, and regression were done accordingly. The paper established that there exists a significant negative relationship between capital structures (DER), a significant relationship between board size and a negative but not significant relationship between board duality and performance (ROA \& ROE) in Nigeria respectively.
\end{abstract}

Keywords: Capital Structure, Board Size, Board Duality.

\section{Introduction}

Generally speaking, the issue of capital structure and board structure (under the corporate governance) are salient areas in corporate finance that are essential for the maximization of shareholders returns, wealth maximization, smooth running of firms operation and even the ability of firms to survive amidst competitions.

Capital is a very crucial ingredient to the existence of any organization because of its direct relation to business continuity and its effect on the ability of the firm to deal with its competitors. Claessens (2003) argued that better corporate frameworks benefit firms through greater access to financing, lower cost of capital, better performance and more favorable treatment of all stakeholders. The position has been stated that a weak board structure does not only lead to poor firm performance but also risky financing patterns. Invariable, the stronger the bond structure of any organization, the better the financing pattern of the firms.

The modern theory of the capital structure originated from the path-breaking contribution of Modigliani and Miller in 1958, famous for the irrelevance theory, since then other theories have emerged and they include; the trade-off theory that deals with the balancing of costs and benefits, the pecking order theory that deals with disparity of information and resolved by an order of preference with respect to sources of finance, the agency cost theory of capital structure which states that an optimal capital structure will be determined by minimizing the costs arising from conflicts between the parties involved. Agency costs play an important role in financing decisions due to the conflict that may exist between shareholders, debt holders and management which brings to 
the fore the importance of corporate governance.

Directors of companies are regarded as a group of senior officers, who primarily formulate policies, manage, control and authorize company's affair which means that they are in charge of the financing decision of their corporation. In summary, a director is the member of a group that directs the affairs of the company (Nnyeruka and Ohaka 2006). The directors can either be inside directors who are employees, officers, major shareholders or people connected to the company, they can also be outside directors of the board who are not otherwise employed by or engaged with the company and does not represent any of its stakeholders but bring outside experience and perspective to the board, keeping a watchful eye on the insider directors and help in resolving disputes between inside directors, or between shareholders and the board. Agency theory argues that due to the separation of ownership and control in modern organizations which creates information asymmetry between corporate owners and managers, the latter are likely to exploit the amount and quality of the information they have to their advantage by engaging in self-serving ventures that are "injurious" to the interest of the former. One of the primary duties of the board of directors is to serve as the monitoring agent for shareholders to check the behavior of corporate managers (Fleischer et al., 1988; and Waldo, 1985).

Effective board structure and capital structure will lead to proper and efficient practice in the administration of business entities. This will ultimately lead to the reduction in the incidence of corporate failures, poor internal control system, poor corporate structure, indiscipline both on the part of management and workers. Poorly governed corporations do not only pose a risk to themselves, they do to others and could indeed pull down capital market since they are less profitably, have more bankruptcy risks, lower valuations and pay out less to their shareholders.

Recent literature on the board of directors is basically empirical and focuses on the size of the board (Jensen, (1993); Yermack, (1996); Fernándezet al., (1997); Huther, (1997); Eisenberg et al., (1998) its composition and independence (Baysinger and Butler, (1985; Hermalin and Weisbach, (1991); Weisbach, (1988); Rosenstein and Wyatt, (1997); Bhagat and Black, (1998);

Much of the public debate on board structure has centered on the pressure for a smaller board size. It is argued that although larger board size helps in the facilitation of key board functions, there comes a point when larger boards suffer from coordination and communication problems and hence board effectiveness (and firm performance) declines (Lipton and Lorsch, (1992); and Jensen, (1993).

The importance of independent non- executive directors in the composition of a board is to effectively monitor the managers and reduce agency cost (Choe and Lee (2003). However, an available theory is scanty on the determinants of optimal board composition (Weisbach, (2002). The question, therefore, is "does the composition of the board of directors influence the firm performance or does firm performance influence the composition of the board of directors? (Davidson \& Rowe, (2004).

The interest in board research is sustained by such issues as the important governance oversight role that boards are expected to play, their negligence to the roles and their association with high-profile corporate failures. There is a long tradition of research arguing to what extent the board of director's composition and size influence their company's performance (Hermalin and Weisbach, (2003); Dalton et al.,(1998).

Existing literature on the relationship between the board composition, board size, and firm performance reflects mixed results.

Despite the interest and numerous studies on corporate boards, empirical results display a remarkable lack of consensus. There have been different views with conflicting results (Zajac and Westphal, (1996). Apart from the above, the findings of the studies have been controversial and inconducive as some reports positive effects, other 
reports negative in the time period and methodologies giving the need for further study.

Therefore, this study is a contribution to the ongoing debate on the examination of the effects of firms' capital structure and board structure on corporate performance. It will also contribute to the existing body of knowledge using Nigerian data to investigate the likely effects of capital structure and board structure on firm performance in Nigeria.

In analyzing this study, the following null hypotheses were formulated:

$\mathrm{H}_{1}$ : There is no positive relationship between a firm's capital structure and its performance in Nigeria.

$\mathrm{HO}_{2}$ : There is no significant relationship between board size and corporate performance of firms in Nigeria.

$\mathrm{HO}_{3}$ : There is no significant relationship between the board composition and corporate performance of firms in Nigeria.

\section{Theoretical Reflections}

There are two broad schools of thought that gave birth to capital structure.

The first school of thought is the relevance theory of capital structure which comprises of the net income approach and the traditional view. They postulated that the cost of capital is determined by the composition of the capital structure of a firm. This suggests that there exist an optimal capital structure that occurs at the point where the cost of capital is at its minimal thereby contributing to the market value of a firm. The net income approach is based on the assumption that the equity and debt capitalization rates remain constant with changes in leverage. If the debt capitalization rate is lower than the equity capitalization rate, with the introduction of more debt, shareholders earnings are increased and firm value in effect lowering the cost of capital.

The tradition view postulates that the mixture of debt and equity can increase firm value by the reduction in the weighted average cost of capital to a certain limit of financial leverage.

The second school of thought is the irrelevance theory of capital structure that includes the Modigliani and miller theory which is based on the assumption that in a perfect market, the composition of firm financing mix does not affect the cost of capital thereby making the capital structure composition irrelevant in the valuation of a firm. Modigliani and Miller (1958) argue that the capital structure of a firm is irrelevant to its market valuation based on some assumptions applicable in an ideal market.

Capital structure theories originated from the path-breaking contribution of Modigliani and Miller in 1958, famous for the irrelevance theory. They were of the opinion that in a world of perfect capital market and no taxes, a firm's financial structure will not influence its cost of capital.

Since then, numerous theories and research works have been developed and they include the pecking order theory of capital structure as introduced by Donaldson (1961). It is based on the assertion that managers have more information about their firms than investors. This disparity of information is resolved by an order of preference with respect to sources of finance. According to Myers (1984), due to adverse selection, firms prefer internal finance to external finance, when outside funds are necessary, firms prefer debt to equity because of lower information costs associated with debt issues.

Secondly, the static trade-off theory of capital structure contrary to the pecking order states that optimal capital structure is obtained where the net tax advantage of debt financing balances leverage-related costs such as financial distress and bankruptcy, holding firm's assets and investment decisions constant (Baxter, 1967 and Altman, 1984) signifying a cost-benefit structure.

Thirdly, the agency theory initially put forward by Berle and Means (1932) and then Jensen and Meckling (1976), agency conflicts arise from the possible divergence of interests between shareholders (principals) and managers (agents) of firms and also when there is a risk of default, The risk of default may create what Myers 
(1977) referred to as an "underinvestment" or "debt overhang" problem. In this case, the debt will have a negative effect on the value of the firm. They stated that an optimal capital structure will be determined by minimizing the costs arising from conflicts between the parties involved.

\subsection{Empirical Reflection on Capital Structure and Firm Performance}

Ibrahim and SayedEbaid (2009) pointed out that capital structure decision has a weak-to-no impact on firm's performance.

Babatunde et al (2014) tried to study the relationship between capital structure and profitability of conglomerate, consumer goods, and financial services firms quoted in Nigeria Stock exchange using the Return on Asset (ROA) and Return on Equity (ROE) as performance proxies. In addition, debt-equity ratio (DER) and debt asset ratio (DAR) were used as capital structure proxies. The results showed an insignificant relationship between return on equity (ROE) and DAR, significant relationship in almost all firms between return on equity and debt to equity. In the financial firms, there is a negative significant relationship between return on equity and debt to assets ratio, the conglomerate firms, there is also a negative relationship between return on assets (ROA) and debt to equity ratio however not significant.

Mohammed and Jaafer (2012) The study tried to extend Abor's (2005) and Gill et al, (2011) finding regarding the effect of capital structure on profitability of the industrial companies listed on Ammon stock exchange using 39 companies from $2004-2009$. The result reveals a significantly negative relation between debt and profitability.

Anthony et al (2010) investigated the relationship between capital structure and profitability of listed non-financial firms in Ghana, covering a seven-year period (2002-2008). Ratios such as return on assets, return on equity and net profit margin was used as indicators for determining the profitability of the firm. Short-term debt, long-term debt, and total debt ratios were also used as indicators for leverage of the firms. The correlation and regression results showed a significantly negative association between leverage and profitability.

Abor (2005) evaluated the relationship of the profitability with a capital structure for firms listed on the Ghana Stock Exchange. He found a positive relation for short-term debt to total assets and return on equity because of low-interest rates. However, a negative relation exists between long-term financing and equity returns, as the long-term debt was more expensive in that market. The relation among total debt and profitability is positive because of the larger proportion of short-term financing in total debt. He suggested that profitable firms are largely dependent on debt as a major source of financing.

Albert, Michael, and Daniel (2013) studied the relationship between capital structure and profitability of listed firms in Ghana during the five year period from 2005 to 2009 using Regression analysis. Similar to Abor (2005) study, the results revealed that, there is a statistically significant positive relationship between profitability and short-term debt and a significantly negative relationship between profitability and long-term debt. However, the results revealed a statistically negative relationship between profitability and total debt contrary to Abor (2005) study.

Akintoye (2008) studied the sensitivity of performance to the capital structure on selected food and beverage companies in Nigeria. The result shows that performance indicators to turnover (Earnings before Interest and Taxes, Earnings per Share and Dividend Per Share) and the measures of leverage (Degree of Operating Leverage, Degree of Financial Leverage and Dividend Per Share) are significantly sensitive.

Zeitun and Tian (2007), supports the relationship between capital structure and firm performance from the agency perspective and also supports a negative relationship using 167 Jordanian companies over fifteen year period (1989-2003), found that a firm's capital structure has a significant negative impact on the firm's 
performance indicators, in both the accounting and market measures.

Majumdar and Chhibber (1997) and Rao, M-Yahyaee, and Syed (2007) also confirm the negative relationship between capital structure and performance. Their results further suggest that liquidity, age, and capital intensity have significant influences on financial performance.

Capon et al. (1990), who suggested that out of the 149 relationships, reported using debt as the independent variable and firm performance as the dependent variable, 90 reported a negative relationship.

Numerous other studies supports a negative relationship Kester(1986), Friend and Lang(1988), Titman and Wessels (1988), Harris and Raviv(1990), Shah (1994), Rajan and Zingales(1995), Wald (1999), Booth et al. (2001) and Fama and French (2002). While others found the relationship to be positive like Roden and Lewellen (1995), Champion (1999), Ghosh et al. (2000), Hadlock and James (2002) and Berger and Bonaccorsi di Patti (2006).

\subsection{Board Structure}

Tricker (1994) noted that board structure distinguishes between those directors who hold management positions in the company and those who do not. Hence with management positions are referred to as insider directors in the United States or executive directors in the United Kingdom and Australia. The top person on the board is the chairman. He could be an executive or a non-executive of the company. If the Chief Executive Officer (CEO) happens to be a director on the board, then he is an executive director.

Agency theory argues that due to the separation of ownership and control in modern organizations which creates information asymmetry between corporate owners and managers, the latter are likely to exploit the amount and quality of the information they have to their advantage by engaging in self-serving ventures that are injurious to the interest of the former. One of the primary duties of the board of directors is to serve as the monitoring agent for shareholders to check the behavior of corporate managers (Fleischer et al., 1988; and Waldo, 1985). Therefore, having an insider-dominated board of directors is likely to exacerbate the situation as the board's role as a monitoring agent of shareholders will be curtailed, paving way for managers to harm shareholders' wealth. Consequently, agency theory argues that effective boards will consist of outside directors.

\subsection{Empirical Reflections On Board Structure and Firm Performance}

Arosa et al. (2010) find that the presence of independent directors on the board of a non-listed family firm has a positive effect on performance when the firm is run by the first generation. However, no effect on performance is seen when the firm is run by the second and subsequent generations.

Andres and Vallelado (2008) concluded that a large board size should be preferred to a small size because of the possibility of specialization for more effective monitoring and advising functions.

Bonn, Yokishawa, and Phan (2004) tried to compare the effects of board structure on firm performance between Japanese and Australian firms, they found that board size and performance was negatively correlated for Japanese firms but no relationship between the two variables for its Australian counterpart was found. However, contrary to the Japanese firms the ratios of outside directors and female directors to total board numbers have a positive impact in the Australian sample.

Hermalin and Weisbach (2003) concluded that although the empirical literature does not infer a relationship between board composition and firm performance, board size is negatively related to corporate performance. (Barnhart, et al., 1994).

Vafeas (2000) reported that firms with the smallest board are better informed about the earnings of the firm and thus can be regarded as having better monitoring abilities.

Forbes \& Milliken (1999) suggested that although large boards may increase the quality of decision-making 
since they offer a broader array of perspectives, their size may hinder the ability to reach a consensus.

Yermack (1996) found that profitability and financial efficiency ratios decrease as a board's size increases.

Jensen (1993) argued that the preference for smaller board size stems from the technological and organizational change which ultimately leads to cost-cutting and downsizing.

Contrary to the above findings, a positive impact on performance was recorded with larger board size by Mak and Li (2001) and Adams and Mehran (2005); Adam and Mehran (2005) found a positive relationship between board size and performance (measured by Tobin's Q) in the U.S banking industry.

Pearce and Zahra, (1992); Rosenstein and Wyatt, (1990); Schellenger et al., (1989) also reported a positive relationship between outside director representation and firm performance.

Studies by Chaganti et al. (1985); Daily and Dalton (1992), (1993); and Zahra and Stanton (1988) have found no relationship between board composition and firm performance.

\section{Research Methodology}

Secondary data consisting of the forty listed companies on the Nigerian Stock Exchange (NSE) within the period of 2008 to 2016.Data are analyzed based on time series - cross-section data. They are merged and pooled for analysis using Regression.

Information relating to firm capital structure (Debt to equity ratio); Board size (Number of directors on the board); Board Duality (Proportion of outside directors sitting on the board);

\section{Model Specification}

The econometric model used in the study is given as:

$\mathrm{Y}=\beta_{0}+\beta_{1} \mathrm{X}_{\mathrm{it}}+{ }_{\mathrm{Kit}}$

Where $\mathrm{Y}$ is the dependent variable. $\beta_{0}$ is the intercept (it gives the value of $\mathrm{Y}$ when $\mathrm{X}$ is zero), $\beta_{1}$ is the slope measuring the rate of change in $\mathrm{Y}$ for a unit change in $\mathrm{X}$ and the coefficient of the explanatory variables (corporate governance mechanisms) in the study, $\mathrm{X}_{\mathrm{it}}$ is the explanatory variable and $\mathrm{E}_{\mathrm{dit}}$ is the error term, mathematically;

Transforming equ. (1 and 2 ) into a testable form, we obtain the following regression equations;

CORPERF $=\beta_{0}+\beta_{1} \mathrm{CS}+\beta_{2} \mathrm{BS}+\mathrm{E}_{2 \mathrm{t}}$

Where CORPERF $=$ Corporate performance which represents the dependent variable.

$\mathrm{CS}=$ Capital structure and BS $=$ Board structure are the independent variables.

$\mathrm{E}_{2 \mathrm{t}}=$ Error term

$\beta_{1}$ and $\beta_{2}$ are the coefficients of the explanatory variables respectively.

In this study, our corporate dependent variable performance will be proxied by Return on Assets (ROA) and Return on Equity (ROE) while Capital Structure (CS) is composed of Debt to Equity Ratio (DER); others are:

$\mathrm{ROA}=\beta_{0}+\beta_{1} \mathrm{DER}+\beta_{2}$ Bsize $+\beta_{3}$ Bcomp $+\mathrm{E}_{3 \mathrm{t}}$

$\mathrm{ROE}=\beta_{0}+\beta_{1} \mathrm{DER}+\beta_{2}$ Bsize $+\beta_{3}$ Bcomp $+\mathrm{E}_{3 \mathrm{t}}$

Where

Return on equity $(\mathrm{ROE})=$ Profit after tax $(\mathrm{PAT}) /$ Total equity shares in issue

Return on asset $(\mathrm{ROA}) \quad=\quad$ Profit after tax $(\mathrm{PAT}) /$ Turnover

Debt to Equity ratio (DER) = Total debt / Total equity

Board size $($ Bsize $)=$ Natural logarithm of the total number of members of the board of directors.

Board Duality (Bcomp) = Proportion of outside or non-executive directors sitting on the board.

For performance evaluation firms employ both financial and non-financial performance criteria.

ROA and ROE were chosen because they are important accounting-based and widely accepted measures of 
financial performance.

5. Results and Discussion of Findings

\subsection{Descriptive Statistics}

The table1 shows the descriptive statistics of all the variables used in the study.The Descriptive procedure displays a summary statistics for several variables in a single table and calculates standardized values. Here, the sample consists of 40 quoted companies on the Nigeria stock exchange. The following items were applied, mean, minimum, maximum, standard deviation, sum, kurtosis and skewness with their probabilities.

A critical examination of the descriptive statistics for the dependent and explanatory variables reveals that all the variables have a positive mean and the average ROA of the sampled firms is about $28 \%$, while that of the ROE is about $15 \%$. The results indicate that on the average, for every $\$ 100$ worth of total assets of the firms, 28 was earned as profit after tax, while $\$ 15$ was earned as after-tax profit on every $\$ 100$ equity share issued.

The average of debt to equity ratio is 5.03; while the average of Board size of 40 firms used in the study is 10 ranging from the minimum of 6 and the maximum of 16 which shows that the size of a board varies substantially among companies. The average of board composition is 0.59 showing that only 59 percent of the board members are independent respectively with a minimum value of 25 percent and a maximum value of 85percent. Also, the probabilities values of Return on Assets and Return on Equity are significant at 5\% confidence level meaning that there is a positive and significant relationship between capital structure, bond structure and corporate performance of firms in Nigeria.

Table 1

\begin{tabular}{|c|c|c|c|c|c|}
\hline & ВСОМР & BSIZE & ROA & DER & ROE \\
\hline Mean & 0.585750 & 10.32500 & 0.275947 & 5.032775 & 0.146598 \\
\hline Median & 0.560000 & 10.00000 & 0.220000 & 0.434000 & 0.110200 \\
\hline Maximum & 0.880000 & 16.00000 & 2.782000 & 177.7520 & 1.374000 \\
\hline Minimum & 0.250000 & 6.000000 & -0.208600 & 0.012000 & -0.208600 \\
\hline Std. Dev. & 0.146967 & 2.535770 & 0.472392 & 28.01534 & 0.256758 \\
\hline Skewness & 0.057854 & 0.384007 & 3.839422 & 6.080913 & 2.678825 \\
\hline Kurtosis & 2.878814 & 2.296248 & 21.03965 & 37.99427 & 14.20627 \\
\hline Jarque-Bera & 0.046791 & 1.808520 & 640.6561 & 2287.515 & 257.1415 \\
\hline Probability & 0.976876 & 0.404841 & 0.000000 & 0.000000 & 0.000000 \\
\hline Sum & 23.43000 & 413.0000 & 11.03786 & 201.3110 & 5.863930 \\
\hline Sum Sq. Dev. & 0.842378 & 250.7750 & 8.703003 & 30609.50 & 2.571053 \\
\hline Observations & 40 & 40 & 40 & 40 & 40 \\
\hline
\end{tabular}

Source: $\quad$ Extracts from E-view print out and Author's Computation, 2017.

\subsection{Correlation Analysis}

Correlation analysis is concerned with describing the strength of the relationship between two variables. In this study, the correlation co-efficient analysis is undertaken to find out the relationship between capital structures, board size and board composition on corporate performance. To show the amount of relationship that exists 
between the variables.

Table 2: ROA as a firm performance measure to capital structure (measured as DER).

\begin{tabular}{llll}
\hline & & ROA & DER \\
\hline \multirow{2}{*}{ ROA } & Pearson Correlation & 1 & -.147 \\
\cline { 2 - 4 } & Sig. (2-tailed) & & .364 \\
\cline { 2 - 4 } & $\mathrm{N}$ & 40 & 40 \\
\hline \multirow{2}{*}{ DER } & Pearson Correlation & -.147 & 1 \\
\cline { 2 - 4 } & Sig. (2-tailed) & .364 & \\
\cline { 2 - 4 } & $\mathrm{N}$ & 40 & 40 \\
\hline
\end{tabular}

Source: Author's Computation

Table 2 shows the relationship between debt to equity DER (measure for capital structure) and return on asset (ROA) a measure of performance. There is a negative relationship between the ROA and DER at $(-0.147)$ at a significance level of 0.01 with a low coefficient of determination at (0.364).

Table 3: ROE as a firm performance measure to capital structure (measured as DER).

\begin{tabular}{llll}
\hline \multirow{2}{*}{ ROE } & & ROE & DER \\
\cline { 2 - 4 } & Pearson Correlation & 1 & -.053 \\
\cline { 2 - 4 } & Sig. (2-tailed) & & .744 \\
\cline { 2 - 4 } & $\mathrm{N}$ & 40 & 40 \\
\hline \multirow{2}{*}{ DER } & Pearson Correlation & -.053 & 1 \\
\cline { 2 - 4 } & Sig. (2-tailed) & .744 & 40 \\
\cline { 2 - 4 } & $\mathrm{N}$ & 40 & 40 \\
\hline
\end{tabular}

Source: Author's Computation

Table 3 above shows the relationship between debt to equity DER (measure for capital structure) and return on equity (ROE) a measure of performance. There is a negative relationship between the ROE and DER at (-0.053) at a significance level of 0.01 with a high coefficient of determination at (0.744).

Table 4: ROA as a firm performance measure to Board composition (BCOMP).

\begin{tabular}{lll}
\hline Correlations & ROA & BCOMP \\
\hline Pearson Correlation & 1 & .026 \\
\hline Sig. (2-tailed) & & .871 \\
\hline $\mathrm{N}$ & 40 & 40 \\
\hline Pearson Correlation & .026 & 1 \\
\hline Sig. (2-tailed) & .871 & \\
\hline $\mathrm{N}$ & 40 & 40 \\
\hline
\end{tabular}

Source: Author's Computation

Table 4 shows the relationship between Board composition (BCOMP) and return on asset (ROA) a measure of performance. There is a positive relationship between the ROA and BCOMP at (0.026) at a significance level of 0.05 with a high coefficient of determination at (0.871). 
Table 5: ROA as a firm performance measure to capital structure (measured as DER).

\begin{tabular}{llll}
\hline & & ROE & BCOMP \\
\hline \multirow{2}{*}{ ROE } & Pearson Correlation & 1 & .252 \\
\cline { 2 - 4 } & Sig. (2-tailed) & & .116 \\
\cline { 2 - 4 } & $\mathrm{N}$ & 40 & 40 \\
\hline \multirow{2}{*}{ BCOMP } & Pearson Correlation & .252 & 1 \\
\cline { 2 - 4 } & Sig. (2-tailed) & .116 & \\
\cline { 2 - 4 } & $\mathrm{N}$ & 40 & 40 \\
\hline
\end{tabular}

Source: Author's Computation

Table 5 shows the relationship between Board composition (BCOMP) and return on equity (ROE) a measure of performance. There is a positive relationship between the ROE and BCOMP at $(0.252)$ at a significance level of 0.01 with a low coefficient of determination at $(0.116)$.

Table 6: ROA as a firm performance measure to Board size (BSIZE).

\begin{tabular}{llll}
\hline & & ROA & BSIZE \\
\hline \multirow{2}{*}{ ROA } & Pearson Correlation & 1 & .206 \\
\cline { 2 - 4 } & Sig. (2-tailed) & & .203 \\
\cline { 2 - 4 } & $\mathrm{N}$ & 40 & 40 \\
\hline \multirow{2}{*}{ BSIZEE } & Pearson Correlation & .206 & 1 \\
\cline { 2 - 4 } & Sig. (2-tailed) & .203 & \\
\cline { 2 - 4 } & $\mathrm{N}$ & 40 & 40 \\
\hline
\end{tabular}

Source: Author's Computation

Table 6 shows the relationship between Board size (BSIZE) and return on equity (ROA) a measure of performance. There is a positive relationship between the ROA and BSIZE at (0.206) at a significance level of 0.05 with a low coefficient of determination at $(0.203)$.

Table 7: ROE as a firm performance measure to Board size (BSIZE).

\begin{tabular}{llll}
\hline & & ROE & BSIZE \\
\hline \multirow{2}{*}{ ROE } & Pearson Correlation & 1 & $.386^{*}$ \\
\cline { 2 - 4 } & Sig. (2-tailed) & & .014 \\
\cline { 2 - 4 } & $\mathrm{N}$ & 40 & 40 \\
\hline \multirow{2}{*}{ BSIZE } & Pearson Correlation & $.386^{*}$ & 1 \\
\cline { 2 - 4 } & Sig. (2-tailed) & .014 & 40 \\
\cline { 2 - 4 } & $\mathrm{N}$ & 40 & \\
\hline
\end{tabular}

Source: Author's Computation

*. Correlation is significant at the 0.05 level (2-tailed).

Table 7, shows the relationship between Board sizes and return on equity (ROE) a measure of performance. There is a positive relationship between the ROE and BSIZE at 0.386 with a low coefficient of determination at 0.014 .

However, descriptive and correlation analysis only indicates the associate link between variables. Hence, the need 
for further analysis.

\subsection{Cointegration Test}

Table 8: this shows the long run relationship between variables.

\begin{tabular}{ccccc}
\hline \multicolumn{5}{l}{ Normalized cointegrating coefficients (standard error in parentheses) } \\
\hline BSIZE & ROA & ROE & BCOMP & DER \\
\hline 1.000000 & 0.000000 & 0.000000 & 0.0 & -0.007836 \\
\hline
\end{tabular}

\subsection{Granger Causality}

Table 9

\begin{tabular}{lccc}
\hline Null Hypothesis: & Obs & F-Statistic & Prob. \\
\hline \hline ROA does not Granger Cause BSIZE & 38 & 2.22348 & 0.1242 \\
\hline BSIZE does not Granger Cause ROA & & 0.53336 & 0.5916 \\
\hline \hline ROE does not Granger Cause BSIZE & 38 & 1.29497 & 0.2875 \\
\hline BSIZE does not Granger Cause ROE & & 2.08834 & 0.1400 \\
\hline \hline DOE does not Granger Cause BSIZE & 38 & 0.68782 & 0.5097 \\
\hline BSIZE does not Granger Cause DER & & 1.03945 & 0.3649 \\
\hline \hline ROE does not Granger Cause ROA & 38 & 0.76387 & 0.4739 \\
\hline ROA does not Granger Cause ROE & & 0.93945 & 0.4010 \\
\hline \hline DOE does not Granger Cause ROA & 38 & 0.00574 & 0.9943 \\
\hline ROA does not Granger Cause DER & 38 & 1.25892 & 0.2972 \\
\hline \hline DOE does not Granger Cause ROE & & 1.77768 & 0.1848 \\
\hline ROE does not Granger Cause DER & & & \\
\hline
\end{tabular}

Source: Author's Computation

Table 9 shows that none of the variables has a cause-effect relationship even though they are correlated.

\subsection{Regression Result (Veto Autoregression Analysis)}

Table 10; ROA as dependent variable on all independent variables (DER, BSIZE, AND BCOMP) with a two year lag of the dependent variable plus each the independent variables.

\begin{tabular}{lllll}
\hline \multicolumn{4}{l}{ Standard errors in ( ) \& t-statistics in [ ] } \\
\hline \hline ROA & BCOMP & BSIZE & DER \\
\hline \hline & & & & \\
\hline ROA $(-1)$ & 0.076280 & -0.025353 & 1.595734 & 2.775061 \\
\hline
\end{tabular}




\begin{tabular}{|c|c|c|c|c|}
\hline & $(0.19250)$ & $(0.06018)$ & $(0.99609)$ & (11.1405) \\
\hline & [ 0.39625$]$ & {$[-0.42127]$} & [ 1.60200$]$ & [ 0.24910$]$ \\
\hline \multirow[t]{3}{*}{$\operatorname{ROA}(-2)$} & 0.122775 & -0.004151 & -0.488644 & -2.580817 \\
\hline & $(0.19465)$ & $(0.06085)$ & $(1.00720)$ & $(11.2648)$ \\
\hline & {$[0.63074]$} & {$[-0.06822]$} & {$[-0.48515]$} & {$[-0.22911]$} \\
\hline \multirow[t]{3}{*}{ BCOMP(-1) } & -0.704506 & -0.065026 & 2.454896 & -44.46992 \\
\hline & $(0.61063)$ & $(0.19090)$ & $(3.15961)$ & $(35.3378)$ \\
\hline & {$[-1.15374]$} & {$[-0.34063]$} & {$[0.77696]$} & {$[-1.25842]$} \\
\hline \multirow[t]{3}{*}{ BCOMP(-2) } & -0.596228 & -0.171614 & -2.704170 & 56.64832 \\
\hline & $(0.68509)$ & $(0.21418)$ & (3.54492) & (39.6473) \\
\hline & {$[-0.87029]$} & {$[-0.80126]$} & {$[-0.76283]$} & [ 1.42881$]$ \\
\hline \multirow[t]{3}{*}{ BSIZE(-1) } & -0.029638 & 0.002080 & 0.004183 & -4.034596 \\
\hline & $(0.04195)$ & $(0.01312)$ & $(0.21709)$ & $(2.42799)$ \\
\hline & {$[0.70642]$} & {$[0.15860]$} & [0.01927] & {$[-1.66170]$} \\
\hline \multirow[t]{3}{*}{ BSIZE(-2) } & 0.003344 & 0.004126 & -0.092841 & -0.552188 \\
\hline & $(0.03976)$ & $(0.01243)$ & $(0.20573)$ & $(2.30095)$ \\
\hline & [ 0.08410$]$ & [ 0.33193] & {$[-0.45127]$} & {$[-0.23998]$} \\
\hline \multirow[t]{3}{*}{$\operatorname{DER}(-1)$} & -0.001417 & -0.000806 & 0.001519 & 0.044145 \\
\hline & $(0.00366)$ & $(0.00114)$ & $(0.01892)$ & $(0.21160)$ \\
\hline & {$[-0.38747]$} & {$[-0.70498]$} & [0.08029] & {$[0.20863]$} \\
\hline \multirow[t]{3}{*}{$\operatorname{DER}(-2)$} & -0.001417 & 0.001020 & 0.013428 & 0.059459 \\
\hline & $(0.00329)$ & $(0.00103)$ & $(0.01704)$ & $(0.19053)$ \\
\hline & {$[-0.43039]$} & [ 0.99068] & [ 0.78827] & [ 0.31207$]$ \\
\hline \multirow[t]{3}{*}{$\mathrm{C}$} & 1.290009 & 0.664585 & 11.05782 & 44.08397 \\
\hline & $(0.85402)$ & $(0.26700)$ & $(4.41904)$ & $(49.4236)$ \\
\hline & {$[1.51051]$} & [ 2.48913] & [2.50231] & [0.89196] \\
\hline R-squared & 0.108986 & 0.123705 & 0.194486 & 0.185419 \\
\hline Adj. R-squared & -0.136811 & -0.118031 & -0.027724 & -0.039293 \\
\hline Sum sq. resids & 7.433493 & 0.726541 & 199.0255 & 24895.55 \\
\hline S.E. equation & 0.506288 & 0.158282 & 2.619723 & 29.29961 \\
\hline F-statistic & 0.443400 & 0.511736 & 0.875234 & 0.825140 \\
\hline
\end{tabular}




\begin{tabular}{lcccc}
\hline Log likelihood & -22.91945 & 21.26423 & -85.38075 & -177.1320 \\
\hline Akaike AIC & 1.679971 & -0.645486 & 4.967408 & 9.796420 \\
\hline Schwarz SC & 2.067820 & -0.257637 & 5.355257 & 10.18427 \\
\hline Mean dependent & 0.297349 & 0.581579 & 10.39474 & 5.281711 \\
\hline S.D. dependent & 0.474847 & 0.149694 & 2.584146 & 28.74040 \\
\hline \hline Determinant resid covariance (dof adj.) & 23.98164 & & \\
\hline Determinant resid covariance & 8.134606 & & \\
\hline Log-likelihood & -255.5051 & & \\
\hline Akaike information criterion & 15.34237 & & \\
\hline Schwarz criterion & 16.89377 & & \\
\hline \hline
\end{tabular}

From table 10, all the variables were lagged by two years to put into consideration the time effect. Since there is no cause-effect relationship between any of the variables even though they are correlated, DER shows a negative relationship for the two years, contrary to the correlation test, the board duality shows a negative relationship and board size a mixed result, the first year showing a negative while the second year was positive, the $\mathrm{R}^{2}$ shows the percentage variation in performance (ROA). By implication, the value 0.10 means that only about 10 percent of the total variation in ROA is as a result of changes both DER, BSIZE and BCOMP. Individually, BCOMP report for $12 \%$ variation in performance, BSIZE has $19 \%$ and DER has $18 \%$. But since they do not a cause-effect relationship, our model will only consist of the group together. This means that there are other factors which affect performance using ROA as a measure which was not included in this study.

According to the above regression analysis, VAR Model is formulated as follows:

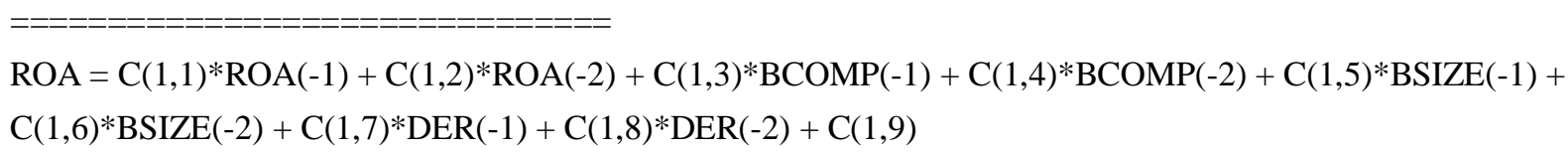

VAR Model - Substituted Coefficients: representing the regression equation.

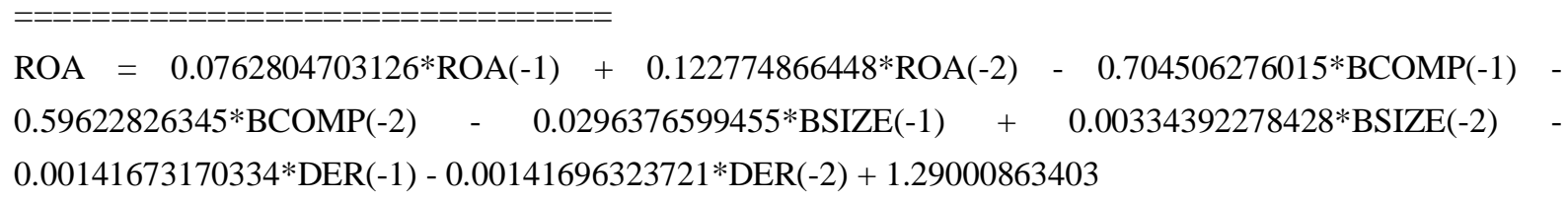

\section{Discussion of Findings}

$\mathrm{Ho}_{1}$ : There is no positive relationship between a firm's capital structure and firm performance in Nigeria.At a $5 \%$ level of significance, ROA and ROE which are measures for performance shows a negative relationship with the debt to equity ratio (a measure of capital structure), ROA at (- 0.147) and ROE at (-0.053), we therefore accept $\mathrm{H}_{1}$ since the research result shows a negative relationship between the capital structure and firm's financial performance. This can be found in the result on table 2 and 3.

$\mathrm{HO}_{2}$ : There is no significant relationship between board size and firm performance of firms in Nigeria.

From table 4 and 5, the correlation analysis shows that there is a positive relationship between board size (BSIZE) and the measures of performance which are ROA and ROE with a coefficient of 0.116 and 0.87 
respectively at a $1 \%$ level of significance. The regression result reports a negative relationship in the first year lag $(-0.030)$ and a positive relationship at the second year lag at $(0.03)$ with a coefficient of $(0.706)$ and (0.084) for ROA and ROE are also positive results for the lags with a coefficient of (1.132) and (1.49) respectively Therefore, we reject the null hypothesis at both $1 \%$ and $5 \%$ level of significance, there is a significant relationship between the board size and performance as recorded by the correlation analysis.

$\mathrm{HO}_{3}$ : There is no significant relationship between the board duality and firm performance of firms in Nigeria.

There exist a relationship between BCOMP and both ROA and ROE from the correlation analysis but the regression result, showed the relationship to be inverse since both the ROA and ROE reported a negative relationship at a significance of (-1.1537) and (-0.8703) for ROA and (-0.413) and (-0.968) for ROE. Therefore we accept the null hypothesis that there is no significant relationship between BCOMP and performance. This shows that the number of independent directors has a negative impact on firm value (ROA) and (ROE) but it is not significant. This result does not support the argument that board with a higher number of independent directors will add more value for firms and this supports previous studies. Board composition is very important since the regression result shows that it can have a negative impact on performance.

\subsection{Summary of the Findings}

Based on our discussion of findings, the following summary was evident from the research analysis;

- A capital structure consists of the combination of both equity and debt as seen in the financial statement of the firms used for the study. Capital structure is also related to ROA and ROE that are measures of performance using the debt to equity ratio as a proxy and also has a negative impact on corporate performance.

- Board size has a significant relationship to ROE and ROA but it has an inconclusive impact on corporate performance since it shows both a positive and negative relationship in the first and second-year lag respectively. The variance in the board size exists because of the different industries and policies governing them like the banks and insurance companies and the size of the firm.

- Board composition is related to ROE and ROA and it has a negative impact on corporate performance that is not significant.

\section{Conclusion and Recommendation}

With the existence of a negative correlation between capital structure and performance, this result can be interpreted that high leverage companies would have less profitability meaning that the debt level is at the optimal level. Other factors that may cause the negative impact includes

- The high cost of external debt given the high-interest rate of borrowing in the country.

- Inefficiency and instability suffered by the market in recent times. In short, it can be called the market condition of the country.

- Business risk which is the basic risk a firm or industry is exposed to as they carry out their activities.

Findings from the regression analysis on board size reflect a negative impact consistent with previous works Hakin (2012) and Frick and Bermia (2009) and a positive impact which shows that reducing the size of boards of directors does not contribute to higher firm performance contradicting those of prior research rendering our interpretation inconclusive.

We, therefore, suggest that there is a need for firms to have policies that ensure the consideration of potential board members' skills before appointment to the board and also, there is the need for continuous training and development for board members to ensure efficient discharge of their responsibilities.

The regression result on board duality suggests that there is no significant relationship between board duality 
and any performance measure used such as Return on Equity (ROE) and Return on Assets (ROA). This means that non-executive directors do not add to the performance of firms in Nigeria. Even though the non- executive directors play a significant role in providing independent advice during corporate decision-making process, while such advice may enhance overall corporate policies, such advice may not be significant enough as to create any economic value added to the overall corporate performance. This can be due to the fact that as outsiders, the non-executive directors may be constrained in term of information hence they rely on the insiders for the information required for the decision making and there may be information asymmetry. Therefore, the introduction of regulations stipulating the number of non-executive or independent directors on the boards of companies, while it is appealing from the agency theory point of view, may not directly enhance performance since the role they play as important as it is, may be of indirect enhancement on performance.

\section{References}

Abor, J. (2005). The Effect of Capital Structure on Profitability: Empirical analysis of listed firms in Ghana. Journal of Risk Finance, 6(5), 438-445.

Adeyemi, S. B., \&Oboh, C. S., (2011).Perceived relationship between Corporate Capital structure, International Journal of Business and Social Science, 2 (19) (special issue)

Adusei, M., (2011). Board structure and Bank performance in Ghana.Journal of money, Investment, and banking, Eurojournals publishing, Inc (Issue 19) HTTP:// www.eurojournals.com/JMIB.htm

Alti, A, (2003).How persistent is the impact of market timing on capital structure?.Working paper.

Akhalumeh P., Ohiokha F., \&Ohiokha G., (2011).Board Composition and Corporate Performance: An Analysis of Evidence from Nigeria.Research Journal of Finance and Accounting,2222-2847

Akerlof, G.A. (1970). The market for 'emons': Quality uncertainty and the market mechanism. Quarterly Journal of Economics, 84(3), 488-500.

Atkeson, A., \&Cole, H., (2005). A Dynamic Theory of Optimal Capital Structure and Executive Compensation. Working paper, 11083.

BabalolaY., (2012). The effects of optimal capital structure on firms' performances in Nigeria.Journal of Emerging Trends in Economics and Management Sciences(JETEMS), 3(2), 131-133.

Babatunde, Y., Akinwunmi O., Khadijah, I., Yusuf S., (2014) Capital Structure and Profitability of quoted firms: The Nigerian perspective (2000-2011). 10th International Academic Conference, Vienna, 978-80-87927-02-1, IISES

Baker, M., \&Wurgler, J., (2002).Market timing and Capital Structure.Journal of Finance, 57.

Black, B.S.,(2001). Does Corporate Governance Matter: A crude test using Russian Data, University of Pennsylvania Law Review, 149, 2131-2150.

Beiner, S., \&Dchmid, M.M., (2005).Agency Conflict, Corporate Governance, and Corporate Diversification -Evidence from Switzerland. Working Paper.

Berk, J., \&Demarzo, P., (2011).Corporate finance.( $2^{\text {nd }}$ edition). Pearson Education Inc. Prentice hall, 75 Arlington street, Boston.

Brennan, M.J., \& Schwartz, E. S., (1984). Optimal Financial Policy and Firm Valuation. Journal of Finance, 39.

Dare, F. D., \& Sola, O., (2010). Capital Structure and Corporate Performance in NigeriaPetroleum Industry: Panel Data Analysis, Journal of Mathematics and Statistics 6 (2),1549-3644, p.168-173.

Dittmar, A., (2004). Capital structure in Corporate Spinoffs. Journal of Business, 77.

Ezeoha, A. E., \&Okafor, F. O., (2010). Local Corporate Ownership and Capital Structure $\quad$ Decisions in 
Nigeria: A Developing Country Perspective", Corporate Governance, 10 (3)249 - 260.

Fama, E., \&French, K.R., (2002). Testing Trade-Off and Pecking Order Predictions About

Dividends and Debt. Review of Financial Studies, 15, 1-33.

Frick, B., \&Bermig, A., (2009). Board Size, Board Composition, and Firm Performance: Empirical Evidence From Germany.Working paper.

Graham, J.R., \&Harvey, C., (2001). The Theory and Practice of Corporate Finance: Evidence from the Field. Journal of Financial Economics, 60, 187-243.

Gitman, L.J., (1985). Principles of Managerial Finance.Harper \& Row: New York (Chapters 12 and 13).

Gompers, P.A., Ishii, J.L., \&Metrick, (2003). A. Corporate Governance and Equity Prices. Working Paper.

Goldstein, R., Ju, N., \& Leland, H., (2001). An EBIT-Based Model of Dynamic Capital Structure.Journal of Business, 74, 483-512.

Hakim B. O., (2012). The Effect of Board Structure and Process Disclosure on Corporate Performance in the Emerging African Markets. Managerial Auditing Journal, 27(2), 156 - 174.

Harris, M., and Raviv, A., (1991).The Theory of Capital Structure.Journal of Finance, 46, 297-

Heydar, M.S., Elham, G., Vahid T. K., and Mohsen, A. K., (2011).Capital Structure and Firm Performance; Evidence from Tehran Stock Exchange.EuroJournals Publishing, Inc, 14, 1450-2889

Htay, S. N., (2012). Better Boards Towards Higher Profitability.World Review of Business Research, 2 (2) $149-163$

James C., Van, H. \&Wachowicz, J. M., (1985). Fundamentals of Financial Management, Prentice-Hall of India: New Delhi (Chapter 17).

Jensen, M.C., \&Meckling, W. H., (1976).Theory of the Firm: Managerial Behavior, Agency Costs and Ownership Structure. Journal of Financial Economics,3, 305-360.

Kajola, S. O., (2008).Corporate Governance and Firm Performance: The Case of Nigerian Listed Firms. European Journal of Economics, Finance and Administrative science, 14.

Klapper, L. \& Love, I., (2004).Corporate Governance, Investor Protection, and Performance in Emerging Markets. Working Paper.

Khan M.Y., \& Jain, P.K., (2002). Cost Accounting and Financial Management, Tata McGraw Hill (Part-4).

Korajczyk, R., \& Levy, A., (2003). Capital Structure Choice: Macroeconomic Conditions and Financial Constraints.Journal of Financial Economics, 68, 75-109.

Kostyuk, A. N., \&Koverga, V., (2006).Board Size and Composition: The Main Tradeoffs. Corporate Board Journal, 2 (1), 48-54.

Kulkarni,.P.V., \&Sathya, B.G. (1999). Financial Management, (ninth revised edition), Himalaya Publishing: Bombay.

Leary, M.T., \& Roberts, M. R., (2005).Do Firms Rebalance their Capital Structures?Journal of Finance, 60.

Luigi, P., \&Sorin, V., (2009).A Review of the Capital Structure Theories. Working paper.

Mehmet, S. T., (2009). The Effect of Board Size on Firm Performance: Evidence from Turkey. The European Journal of Finance, 15 (4), 385- 404

Modigliani, F., \&Miller, M.H., (1958).The Cost of Capital, Corporate Finance and the Theory of Investment. American Economic Review,48, 261-297.

Modigliani, F., \& Miller, M.H., (1963).Corporate Income Taxes and the Cost of Capital: A Correction.American Economic Review, 53, 433-443. 
Mohammad, F. S., Jaafer, M. A., (2012). The Relationship between Capital Structure and Profitability.International Journal of Business and Social Science, 3 (16) [Special Issue].

Murray Z.F., \&Vidhan K.G., (2007).Trade-off and Pecking Order Theories of Debt.

Working paper, NBER 16180.

Myers, S.C., \&Majluf, N.S., (1984). Corporate Financing and Investment Decisions when firms have Information that Investors do not have. Journal of Financial Economics, 13, 187-221.

Olayinka, M. U., (2010). The Impact of Board Structure on Corporate Performance in Nigeria.International Journal of Business and Management, 5 (10).

Omorogie, N. A., \&Erah, D. O., (2010).Capital Structure and Corporate Performance in Nigeria: An Empirical Investigation. AAU JMS, 1(1).

Onaolapo, A. A.,\&Kajola, S. O., (2010. Capital Structure and Firm Performance: Evidence from Nigeria. European Journal of Economics, Finance and Administrative Sciences, 25, 1450-2275.

O'Sullivan, N., \&Diacon, S. R., (2002).Board Composition and Performance in UK Life Insurance Companies.Centre for Risk and Insurance Studies, Nottingham University Business School.

Pandey, I.M., (2010). Financial Management.(10 ${ }^{\text {th }}$ Edition).Vikas Publishing House, PVT limited, New Delhi.

Pratheepkanth, P., (2011). Capital Structure and Financial Performance: Evidence From Selected Business Companies. Sri Lanka International Refereed Research Journal, II (2).

Prashat, G., Aman, S., \& Dinesh, S., (2011).Capital Structure and Financial Performance; Evidence from India. Gautam Buddha University, Greater Noida, India.

Rouf, M.A., (2011). The Relationship between Corporate Governance and Value of the Firm in Developing Countries: Evidence from Bangladesh. The International Journal of Applied Economics and Finance, 5(3), 237-244.

San, T. O., \&Heng, B., (2011).Capital Structure and Corporate Performance of Malaysian Construction Sector. International Journal of Humanities and Social Sciences, 1(2).

Shleifer, A, \&Vishny, R.W., (1997).A Survey of Corporate Governance.Journal of Financial Economics, 52(2), 737- 783.

Stiglitz, J. E., (1969). A Re-Examination of the Modigliani-Miller Theorem. America Economic Review, 59, 784-793.

\section{Copyrights}

Copyright for this article is retained by the author(s), with first publication rights granted to the journal.

This is an open-access article distributed under the terms and conditions of the Creative Commons Attribution license (http://creativecommons.org/licenses/by/4.0/). 